\title{
Rare Diseases and COVID-19: How are the Patients?
}

Hercílio Martelli-Júnior 1,2, Renato Assis Machado ${ }^{3,4}$ [D, Aluísio Eustáquio de Freitas Miranda Filho², Juliana de Lima Gonçalves², Mário Sérgio Oliveira Swerts²

${ }^{1}$ Oral Diagnosis, Dental School, State University of Montes Claros, Montes Claros, MG, Brazil.

${ }^{2}$ Center for Rehabilitation of Craniofacial Anomalies, Dental School, University of José do Rosário Vellano, MG, Brazil.

${ }^{3}$ Hospital for Rehabilitation of Craniofacial Anomalies, University of São Paulo, Bauru, SP, Brazil.

${ }^{4}$ Department of Oral Diagnosis, Dental School, University of Campinas, Piracicaba, SP, Brazil.

Corresponding author:

Renato Assis Machado - ORCID: 0000-0002-1697-3662

E-mail: renatoassismachado@yahoo.com.br

Received: 24 July 2020 / Review: 29 September 2020 / Accepted: 03 October 2020

Dear Editor,

When searching the scientific literature COVID-19-associated syndromes in addition to syndromes middle eastern respiratory syndrome (MERS), severe acute respiratory syndrome (SARS), some cardiovascular syndromes and post intensive care syndrome [1,2], we found the syndromes of Guillain-Barré, Miller Fisher, polyneuritis cranialis, Kawasaki, Inflammatory multisystem syndrome, and syndrome of inappropriate antidiuretic hormone secretion [3-29]. Of these, only Guillain-Barré syndrome and Miller Fisher syndrome, Kawasaki diseases and Inflammatory multisystem syndrome have currently present cranio-facial manifestation (Table 1), but possibly others will become know when the damage of COVID-19 becomes known.

Although there is no standardized definition of rare diseases, the classification of rare diseases is closely related to a definition according to point prevalence in the current political and legislative context, and such definitions are based on a prevalence threshold directly or implied. According to the World Health Organization (WOS) and adopted by the Ministry of Health of Brazil, a rare disease affects up to 65 per 100,000 individuals [30]. Each rare disease, taken separately, affects a limited number of people. Considering, however, that there are up to 8,000 types of rare diseases worldwide, when grouped under a single category, their epidemiological impact may become quite significant. About $80 \%$ of those are caused by genetic factors, and the rest by other factors, such as environmental, infectious and immunologicalones [31]. Thus, rare diseases are a global challenge that must be overcome. A multi-professional and interdisciplinary team, including pediatric dentistry, oral medicine and pathology, is essential for success throughout the process.

Approaches involving rare diseases have been a constant concern by WHO. On 21 February 2019 Nata Menabde, Executive Director, WHO office at the United Nations moderated a session to commemorate Rare Diseases Day. She highlighted the importance of including efficient and equitable health care systems in order to reduce inequalities to ensure no one is left behind, including persons with rare diseases, as we strive to achieve the 2030 Agenda for Sustainable Development (https://www.who.int/news-room/featurestories/detail/rare-diseases). 
Table 1. Characteristics of the patients with COVID-19-associated syndromes.

\begin{tabular}{lcccc} 
Syndrome & $\begin{array}{c}\text { Number of } \\
\text { Cases }\end{array}$ & Systemic Manifestations \\
\hline Guillain-Barré & 37 & Acute weakness in both leos; lower-limb
\end{tabular}

Guillain-Barré

Syndrome (\#139393)

Kawasaki Disease

26

\section{Inflammatory}

Multisystem Syndrome weakness; lower-limb and upper-limb paresthesia; generalized areflexia; ataxia; flaccid areflexic paraplegia; severe fatigue; and respiratory failure.

Polymorphous maculopapular rash, and swelling of the hands and lower extremities

Polymorphic rash, swelling (palms and soles), conjunctivitis, decreased appetite, diarrhea, dysuria, abdominal pain, hypotension or shock, severe cardiac illness, or severe end-organ illness

\section{ranio-Facial Manifestations}

Flaccid areflexic tetraplegia;

facial weakness; facial diplegia;

ataxia; and paresthesia.

Limbic-sparing conjunctivitis; dry cracked lips, prominent tongue papilla

Dry, cracked, erythematous lips
Right internuclear ophthalmoparesis, right fascicular oculomotor palsy

\section{PCR Assay for}

Positive

Positive

Jones et al., $2020\lceil 4\rceil$; Labé et al., 2020 [5]; Toubiana et al., 2020 [6]; Whittaker et al., 2020 [7]

Positive and Toubiana et al., $2020[6]$; Whittaker et al., 2020 [7]; Belot et al., 2020 [8]; Capone et al., 2020 [9]; Cheung et al., 2020 [10]; Chiotos et al., 2020 [11]; Dasgupta and Finch, 2020 [12]; Davies et al., 2020 [13]; Dufort et al., 2020 [14]; Greene et al., 2020 [15]; Lee et al., 2020 [16]; Perez-Toledo et al., 2020 [17]; Pouletty et al., 2020 [18]; Ramcharan et al., 2020 [19]; Regev et al., 2020 [20]; Rivera-Figuerosa et al., 2020 [21]; Riollano-Cruz et al., 2020 [22]; Sokolovsky et al., 2020 [23]; Verdoni et al., 2020 [24];

\section{Miller Fisher}

Syndrome and Miller

albuminocytologic dissociation.

Positive

\section{Fisher-like Syndrome}

Syndrome of

Antidiuretic Hormone

Secretion

Polyneuritis Cranialis
Fever; evidence of pneumonia (abnormal chest X-ray depicting bilateral infiltrates); euvolemic hyponatremia $(<135 \mathrm{mmol} / \mathrm{L})$ with concurrent low serum and high urine osmolality $(<280$ and $>100 \mathrm{osmol} / \mathrm{kgH}_{2} \mathrm{O}$, respectively) and high urine sodium $(>40 \mathrm{mmol} / \mathrm{L})$.

Ageusia; bilateral abducens palsy; areflexia and albuminocytologic dissociation. [26]; Lantos et al., 2020 [27]; ReyesBueno et al., 2020 [28]

Positive

(a)

\begin{tabular}{|c|c|c|}
\hline - & Positive & Yousaf et al., 2020 [29] \\
\hline- & Positive & Gutiérrez-Ortiz et al., 2020 [25] \\
\hline
\end{tabular}


Wakap et al. [32] found that the evidence-based population prevalence estimate of 3.5-5.9\%, which is equivalent to 263-446 million people affected globally at any point in time, is still conservative. Many of these diseases still have limited understanding of their pathogenesis and/or limited efforts towards targeted therapy development. Due to the unusual existence of such diseases, it remains a long-recognized challenge for physicians, scientists and patient advocacy organizations to convince government agencies and businesses to provide the requisite funding to research them and to establish efficient and accessible therapies [32].

In this period of pandemic, with the numerous limitations and performance of health services, particularly dental clinics, oral medicine services and clinical genetics, we have a reflection and concern about these millions of patients with rare diseases and how they are being systematically monitored. Successful experiences have been presented with actions directed to patients and professionals remotely in three main lines: (1) care and treatment aspects directly related to rare diseases; (2) psychological aspects that the emergency itself produces or amplifies; and (3) social and legal aspects that influence the life of the individual concerned at work and in relationships [33-35].

Thus, an intense collaboration between services, telemedicine groups and also the opening of communication and monitoring channels for these patients is fundamental, particularly with regard to dentistry.

\section{Acknowledgments}

The CAPES (Coordination of Training of Higher Education Graduate Foundation, Brasilia, Brazil), the CNPq (National Council for Scientific and Technological Development, Brazil), and the FAPEMIG (Minas Gerais State Research Foundation, Minas Gerais, Brazil).

\section{References}

[1] Hendren NS, Drazner MH, Bozkurt B, Cooper LT Jr. Description and Proposed Management of the Acute COVID19 Cardiovascular $\quad$ Syndrome $\quad$ Circulation $\quad 2020$; $\quad 141(23): 1903-14$. https://doi.org/10.1161/CIRCULATIONAHA.120.047349

[2] Stam HJ, Stucki G, Bickenbach J. Covid-19 and Post Intensive Care Syndrome: A Call for Action. J Rehabil Med 2020; 52(4):jrm00044. https://doi.org/10.2340/16501977-2677

[3] Caress JB, Castoro RJ, Simmons Z, Scelsa SN, Lewis RA, Ahlawat A, et al. COVID-19 - associated Guillain-Barre Syndrome: the early pandemic experience. Muscle \& Nerve 2020; 62(4):485-91. https://doi.org/10.1002/mus.27024

[4] Jones VG, Mills M, Suarez D, Hogan CA, Yeh D, Segal JB, et al. COVID-19 and Kawasaki Disease: Novel virus and novel case. Hosp Pediatr 2020; 10(6):537-40. https://doi.org/10.1542/hpeds.2020-0123

[5] Labé P, Ly A, Sin C, Nasser M, Chapelon-Fromont E, Ben Saïd P, et al. Erythema multiforme and Kawasaki disease associated with COVID-19 infection in children. J Eur Acad Dermatol Venereol 2020; 34(10):e539-e541. https://doi.org/10.1111/jdv.16666

[6] Toubiana J, Poirault C, Corsia A, Bajolle F, Fourgeaud J, Angoulvant F, et al. Kawasaki-like multisystem inflammatory syndrome in children during the covid-19 pandemic in Paris, France: prospective observational study. BMJ 2020; 369:m2094. https://doi.org/10.1136/bmj.m2094

[7] Whittaker E, Bamford A, Kenny J, Kaforou M, Jones CE, Shah P, et al. Clinical characteristics of 58 children with a pediatric inflammatory multisystem syndrome temporally associated with SARS-CoV-2. JAMA 2020; 324(3):259-69. https://doi.org/10.1001/jama.2020.10369

[8] Belot A, Antona D, Renolleau S, Javouhey E, Hentgen V, Angoulvant F, et al. SARS-CoV-2-related paediatric inflammatory multisystem syndrome, an epidemiological study, France, 1 March to 17 May 2020. Euro Surveill 2020; 25(22):2001010. https://doi.org/10.2807/1560-7917.ES.2020.25.22.2001010

[9] Capone CA, Subramony A, Sweberg T, Schneider J, Shah S, Rubin L, et al. Characteristics, cardiac involvement, and outcomes of Multisystem Inflammatory Disease of Childhood (MIS-C) associated with SARS-CoV-2 Infection. J Pediatr 2020; 224:1411-5. https://doi.org/10.1016/j.jpeds.2020.06.044

[10] Cheung EW, Zachariah P, Gorelik M, Boneparth A, Kernie SG, Orange JS, et al. Multisystem inflammatory syndrome related to COVID-19 in previously healthy children and adolescents in New York City. JAMA 2020; 324(3):294-6. https://doi.org/10.1001/jama.2020.10374 
[11] Chiotos K, Bassiri H, Behrens EM, Blatz AM, Chang J, Diorio C, et al. Multisystem inflammatory syndrome in children during the coronavirus 2019 pandemic: a case series. J Pediatric Infect Dis Soc 2020; 9(3):393-8. https://doi.org/10.1093/jpids/piaa069

[12] Dasgupta K, Finch SE. A Case of pediatric multisystem inflammatory syndrome temporally associated with COVID19 in South Dakota. S D Med 2020; 73(6):246-51.

[13] Davies P, Evans C, Kanthimathinathan HK, Lillie J, Brierley J, Waters G, et al. Intensive care admissions of children with paediatric inflammatory multisystem syndrome temporally associated with SARS-CoV-2 (PIMS-TS) in the UK: a multicentre observational study. Lancet 2020; 4(9):669-77. https://doi.org/10.1016/S2352-4642(20)302 15-7

[14] Dufort EM, Koumans EH, Chow EJ, Rosenthal EM, Muse A, Rowlands J, et al. Multisystem inflammatory syndrome in children in New York State. N Engl J Med 2020; 383(4):347-58. https://doi.org/10.1056/NEJMoa202 1756

[15] Greene AG, Saleh M, Roseman E, Sinert R. Toxic shock-like syndrome and COVID-19: A case report of multisystem inflammatory syndrome in children (MIS-C). Am J Emerg Med 2020; So735-6757(20)30492-7. https://doi.org/10.1016/j.ajem.2020.05.117

[16] Lee PY, Day-Lewis M, Henderson LA, Friedman K, Lo J, Roberts JE, et al. Distinct clinical and immunological features of SARS-COV-2-induced multisystem inflammatory syndrome in children. J Clin Invest 2020; 141113. https://doi.org/10.1172/JCI 141113

[17] Perez-Toledo M, Faustini SE, Jossi SE, Shields AM, Kanthimathinathan HK, Allen JD, et al. Serology confirms SARS-CoV-2 infection in PCR-negative children presenting with Paediatric Inflammatory Multi-System Syndrome. medRxiv Preprint. 2020. https://doi.org/10.1101/2020.06.05.20123117

[18] Pouletty M, Borocco C, Ouldali N, Caseris M, Basmaci R, Lachaume N, et al., Paediatric multisystem inflammatory syndrome temporally associated with SARS-CoV-2 mimicking Kawasaki disease (Kawa-COVID-19): a multicentre cohort. Ann Rheum Dis 2020; 79(8):999-1006. https://doi.org/10.1136/annrheumdis-2020-2 17960

[19] Ramcharan T, Nolan O, Lai CY, Prabhu N, Krishnamurthy R, Richter AG, et al. Paediatric Inflammatory Multisystem Syndrome: temporally associated with SARS-CoV-2 (PIMS-TS): cardiac features, management and short-term outcomes at a UK tertiary paediatric hospital. Pediatr Cardiol 2020; 1-11. https://doi.org/10.1007/s00246-020-02391-2

[20] Regev T, Antebi M, Eytan D, Shachor-Meyouhas Y, Ilivitzki A, Aviel YB, et al. Pediatric inflammatory multisystem syndrome with central nervous system involvement and hypocomplementemia following SARS-COV-2 infection. Pediatr Infect Dis J 2020; 39(8):e206-e207. https://doi.org/10.1097/INF.0000000000002804

[21] Rivera-Figueroa EI, Santos R, Simpson S, Garg P. Incomplete Kawasaki disease in a child with Covid-19. Indian Pediatr 2020; 57(7):680-1. https://doi.org/10.1007/s13312-020-1900-0

[22] Riollano-Cruz M, Akkoyun E, Briceno-Brito E, Kowalsky S, Rosada R, Sordillo EM, et al. Multisystem Inflammatory Syndrome in Children (MIS-C) related to COVID-19: A New York City experience. J Med Virol 2020. https://doi.org/10.1002/jmv.26224.

[23] Sokolovsky S, Soni P, Hoffman T, Kahn P, Scheers-Masters J. COVID-19 associated Kawasaki-like multisystem inflammatory disease in an adult. Am J Emerg Med 2020. https://doi.org/10.1016/j.ajem.2020.06.053.

[24] Verdoni L, Mazza A, Gervasoni A, Martelli L, Ruggeri M, Ciuffreda M, et al. An outbreak of severe Kawasaki-like disease at the Italian epicentre of the SARS-CoV-2 epidemic: an observational cohort study. Lancet 2020; 395(10239):1771-8. https://doi.org/10.1016/So140-6736(20)31103-X

[25] Gutiérrez-Ortiz C, Méndez-Guerrero A, Rodrigo-Rey S, Pedro-Murillo ES, Bermejo-Guerrero L, Gordo-Mañas R, et al. Miller Fisher Syndrome and polyneuritis cranialis in COVID-19. Neurology 2020; 95(5):e601-e605. https://doi.org/10.1212/WNL.0000000000009619

[26] Fernández-Domínguez J, Ameijide-Sanluis E, García-Cabo C, García-Rodríguez R, Mateos V. Miller-Fisher-like syndrome related to SARS-CoV-2 infection (COVID 19). J Neurol 2020.

https://doi.org/10.1007/s00415-020-09912-2

[27] Lantos JE, Strauss SB, Lin E. COVID-19 - Associated Miller Fisher Syndrome: MRI findings. AJNR Am J Neuroradiol 2020; 41(7):1 184-6. https://doi.org/10.3174/ajnr.A6609

[28] Reyes-Bueno JA, García-Trujillo L, Urbaneja P, Ciano-Petersen NL, Postigo-Pozo MJ, Martínez-Tomás C, et al. Miller-Fisher syndrome after SARS-CoV-2 infection. Eur J Neurol 2020. https://doi.org/10.1111/ene.14383

[29] Yousaf Z, Al-Shokri SD, Al-soub H, Mohamed MFH. COVID-19-associated SIADH: a clue in the times of pandemic! Am J Physiol Endocrinol Metab 2020; 318(6):E882-E885. https://doi.org/10.1152/ajpendo.00178.2020

[30] Martelli DRB, Martelli Júnior H. Undiagnosed and rare diseases: current challenges, perspectives and contribution of oral cavity examination. Oral Surg Oral Med Oral Pathol Oral Radiol 2020; 130(2):227-8. https://doi.org/10.1016/j.0ooo.2020.04.011

[31] Ramalle-Gómara E, Ruiz E, Quinones C, Andres S, Iruzubieta J, Gil-de-Gómez J. General knowledge and opinion of future health care and non-health care professionals on rare diseases. J Eval Clin Pract 2015; 21(2):198-201. https://doi.org/10.1111/jep.12281

[32] Wakap SN, Lambert DM, Olry A, Rodwell C, Gueydan C, Lanneau V, et al. Estimating cumulative point prevalence of rare diseases: analysis of the Orphanet database. Eur J Hum Genet 2020; 28:165-73. https://doi.org/10.1038/s41431-019-0508-0 
[33] Brizola E, Adami G, Baroncelli GI, Bedeschi MF, Berardi P, Boero S, et al. Providing high-quality care remotely to patients with rare bone diseases during COVID-19 pandemic. Orphanet J Rare Dis 2020; 15(1):228. https://doi.org/10.1186/s13023-020-01513-6

[34] Fiumara A, Lanzafame G, Arena A, Sapuppo A, Raudino F, Pratico A, et al. COVID-19 Pandemic Outbreak and its psychological impact on patients with rare lysosomal diseases. J Clin Med 2020; 9(9):E2716. https://doi.org/10.3390/jcm9092716

[35] Costamagna G, Abati E, Bresolin N, Comi GP, Corti S. Management of patients with neuromuscular disorders at the time of the SARS-CoV-2 pandemic. J Neurol 2020; 1-12. https://doi.org/10.1007/s00415-020-10149-2 